\title{
ANALISIS FAKTOR - FAKTOR YANG MEMPENGARUHI MINAT MASYARAKAT DALAM MENGGUNAKAN JASA KOPERASI KRED- IT KUBU GUNUNG TEGALJAYA DI DESA PANCASARI
}

\author{
M. Rudi Irwansyah \\ Jurusan Pendidikan Ekonomi \\ Universitas Pendidikan Ganesha \\ Singaraja, Indonesia \\ e-mail: rudi.irwansyah@undiksha.ac.id
}

\begin{abstract}
Abstrak
Tujuan dari penelitian ini adalah untuk menganalisis faktor - faktor yang mempengaruhi minat masyarakat dalam menggunakan jasa koperasi kredit kubu gunung tegaljaya di desa pancasari. Subjek penelitian ini adalah koperasi kredit Kubu Gunung Tegaljaya sedangkan objek penelitian adalah Tingkat Suku Bunga $\left(X_{1}\right)$, Promosi $\left(X_{2}\right)$, Kepuasan Anggota $\left(X_{3}\right)$, SHU $\left(X_{4}\right)$, Kinerja Karyawan $\left(X_{5}\right)$ dan Minat Masyarakat $(Y)$. Penelitian ini adalah penelitian kuantitatif kausal yang digunakan untuk memperoleh temuan yang teruji mengenai Analisis Faktor - Faktor Yang Mempengaruhi Minat Masyarakat Dalam Menggunakan Jasa Koperasi Kredit Kubu Gunung Tegaljaya Di Desa Pancasari. Hasil penelitian menunjukan bahwa Tingkat Suku Bunga (X1) dengan nilai signifikansi $0.009<0.01$, Promosi $(X 2)$ dengan nilai signifikansi $0.000<0.01$, Kepuasan Anggota (X3) dengan nilai signifikansi $0.002<0.01$, Sisa Hasil Usaha (X4) dengan nilai signifikansi $0.000<0.01$, Kinerja Karyawan (X5) dengan nilai signifikansi $0.000<0.01$.
\end{abstract}

Kata Kunci: Minat masyarakat, Jasa Koperasi

\begin{abstract}
The purpose of this research was to analyze the factors that influence people's interest in using credit cooperative services in the Kubu Gunung Tegaljaya in Pancasari Village. The subject of this research is Kubu Gunung Tegaljaya in Pancasari Village while the research object is the Interest Rate (X1), Promotion (X2), Member Satisfaction (X3), SHU (X4), Employee Performance (X5) and Community Interest (Y). this research is a causal quantitative research that is used to obtain tested findings regarding the Analysis of Factors Affecting the Interest of the Community in Using the Credit Cooperative Services of Kubu Gunung Tegaljaya in Pancasari Village. The results showed that the Interest Rate (X1) with a significance value of $0.009<0.01$, Promotion (X2) with a significance value of $0.000<0.01$, Member Satisfaction (X3) with a significance value of $0.002<0.01$, Remaining Business Results (X4) with a significance value of $0.000<0.01$, Employee Performance (X5) with a significance value of $0.000<0.01$.
\end{abstract}

Keywords: Community interest, Cooperative Services

\section{PENDAHULUAN}

Tingkat kemakmuran negara diantaranya dapat terlihat dari pendapatan nasional dan tingkat pertumbuhan ekonomi. Tingkat pendapatan nasional dan pertumbuhan ekonomi tergantung dari aktivitas ekonomi suatu negara. Para pelaku ekonomi baik perusahaan besar maupun kecil yang berbentuk industri maupun rumah tangga bertujuan untuk memajukan kesejahteraan anggota dan masyarakat. Menghadapi keterpurukan perekonomian Indonesia yang ditandai dengan adanya penurunan nilai tukar rupiah dan disertai dengan kenaikan barang-barang, para pelaku ekonomi baik perusahaan besar 
maupun industri rumah tangga mempunyai peranan penting dalam menggerakkan roda perekonomian masyarakat. salah satu organisasi ekonomi yang memiliki kesempatan usaha yang luas terutama menyangkut kepentingan kehidupan ekonomi rakyat adalah koperasi.

Koperasi merupakan organisasi ekonomi rakyat yang berwatak sosial, beranggotakan orang-orang atau badanbadan hukum koperasi yang merupakan tata susunan ekonomi sebagai usaha bersama berdasarkan atas asas kekeluargaan (Pasal 3 UU No. 12 Tahun 1967). tujuan koperasi adalah untuk memajukan kesejahteraan anggota pada khususnya dan masyarakat pada umumnya, ikut serta membangun tatanan perekonomian Nasional dalam rangka mewujudkan masyarakat yang maju, adil dan makmur berlandaskan Pancasila dan Undang-Undang Dasar 1945. Salah satu jenis koperasi yang umum digunakan oleh masyarakat adalah Koperasi Simpan Pinjam (KSP). Koperasi adalah badan hukum yang didirikan oleh orang perseorangan atau badan hukum koperasi, dengan pemisahan kekayaan para anggotanya sebagai modal untuk menjalankan usaha, yang memenuhi aspirasi dan kebutuhan bersama dibidang ekonomi, sosial, dan budaya sesuai dengan nilai dan prinsip Koperasi. Perkoperasian adalah segala sesuatu yang menyangkut kehidupan Koperasi (Undang-Undang Republik Indonesia Nomor 17 Tahun 2012 tentang Perkoperasian, 2012:1).

Pengertian koperasi telah dikemukakan oleh beberapa pakar koperasi. Koesoemo (Razak, 2012:3) yang menyatakan bahwa koperasi adalah "perkumpulan manusia seorang-seorang yang dengan sukanya sendiri hendak bekerja sama untuk memajukan ekonominya". Selain itu koperasi adalah "suatu perkumpulan dari orang-orang atas dasar persamaan derajat sebagai manusia, dengan tidak memandang haluan agama dan politik secara suka rela masuk untuk sekedar memenuhi kebutuhan bersamanya yang bersifat keberadaan atas tanggungan bersama". Selanjutnya, dalam pasal 1 ayat 1 Undang-Undang No. 17 Tahun 2012 tentang perkoperasian, dinyatakan bahwa koperasi adalah badan hukum yang didirikan oleh orang perseorangan atau bbadan hukum koperasi, dengan pemisahan kekayaan para anggotanya sebagai modal untuk menjalankan usaha, yang memenuhi aspirasi dan kebutuhan bersama di bidang ekonomi, sosial, dan budaya sesuai dengan nilai dan prinsip koperasi.

Koperasi Simpan Pinjam adalah koperasi yang kegiatannya untuk menghimpun dana dan menyalurkan melalui kegiatan simpan pinjam dari dan untuk anggota koperasi yang bersangkutan, calon anggota koperasi yang bersagkutan, koperasi lain dan atau anggotanya (Rudianto : 2006). Menurut Burhanuddin (2010) mengungkapkan bahwa Koperasi Simpan Pinjam adalah koperasi yang didirikan guna memberikan kesempatan kepada para anggotanya untuk memperoleh pinjaman atas dasar kebaikan. Koperasi Simpan Pinjam (KSP) harus mampu untuk mengelola modal dan dana yang ada sehingga dana yang diterima dari masyarakat selanjutnya dapat diberikan kembali kepada masyarakat dalam bentuk kredit. Kredit merupakan kebutuhan yang sangat penting dan sangat dibutuhkan oleh masyarakat Indonesia terutama untuk masyarakat kelas kecil dan kelas menengah. Kebutuhan kredit bisa mendorong kegiatan perdagangan, melancarkan produksi, jasa-jasa maupun untuk kebutuhan konsumsi, pada akhirnya ditujukan untuk menaikkan taraf hidup masyarakat.

Salah satu koperasi yang populer di desa pancasari adalah koperasi kredit kubu gunung tegal jaya, koperasi ini sering digunakan oleh masyarakat pancasari dan masyarakat di luar desa pancasari. Kopdit kubu gunung tegal jaya dibentuk pada bulan april 1991 Dibentuk pada bulan April 1991 dengan nama Koperasi Kredit Rumah Khalwat Tegaljaya. Karena para pendirinya sebagian besar adalah karyawan dari Rumah Khalwat Tegaljaya dan kantor juga terletak di Rumah Khalwat Tegaljaya. Tahun ke 3 Kopdit Rumah Khalwat Tegaljaya membeli sebidang tanah untuk kantor di jalan Kubu gunung, dan pembangunannya dikerjakan oleh salah seorang anggota yang pekerjaannya sebagai pemborong.Th. 1998 pengurus berhasil memperoleh Badan Hukum koperasi dengan nomor : 02/BH/KDK $22.7 / X / 1998$, sekaligus berubah nama menjadi Koperasi Kredit Kubu Gunung Tegaljaya. Sejak memiliki kantor sendiri, 
Kopdit Kubu Gunung Tegaljaya semakin diminati masyarakat dan mengalami perkembangan yang cukup pesat, Kopdit Kubu Gunung Tegaljaya juga membuka diri menerima tenaga-tenaga magang dan kunjungan-kunjungan dari koperasi - koperasi lain termasuk dari luar negeri. Sebaliknya untuk pengembangan Kopdit, pengurus dan manajemen setiap ada kesempatan selalu mengikuti pelatihan-pelatihan. Sejak awal tahun 2013 Kopdit Kubu Gunung sudah menggunakan sistem online yang bernama Sicundo (Sistem Credit Union Indonesia) yang berbasis open source, Anggota bisa mengecek saldo online dan Petugas Lapangan / Kolektor menggunakan perangkat Handphone (android) dan Mini Printer Bluetoth untuk transaksi Anggota Keliling. Ditambah den- gan SMS Masking untuk memberikan layanan informasi kepada Anggota dalam bentuk SMS. Akan tetapi karena sekarang banyak persaingan dari sesama koperasi, bank, finance dan lembaga keuangan lainnya, jumlah anggota koperasi kredit kubu gunung tegaljaya mulai berkurang, dan tentunya mengakibatkan transaksi koperasi juga berkurang dan menghambat pertumbuhan koperasi ini, oleh sebab itu maka kami melakukan penelitian mengenai penyebab menurunnya minat masyarakat terhadap koperasi kredit kubu gunung tegaljaya.

Berdasarkan pengamatan awal pada Kopdit Kubu Gunung Tegaljaya diperoleh data jumlah anggota dari tahun 2015-2017 seperti nampak pada tabel 1.

Tabel 1. Data jumlah anggota Kopdit Gunung Tegaljaya

\begin{tabular}{lll}
\hline Nama Koperasi & Tahun & \multicolumn{1}{c}{ Jumlah anggota } \\
\hline Kopdit Kubu Gunung Tegaljaya & 2015 & 5.549 \\
& 2016 & 5.703 \\
& 2017 & 5.057 \\
\hline
\end{tabular}

Berdasarkan Tabel 1 tahun 2015-2016 terjadi kenaikan jumlah anggota pada Kopdit Kubu Gunung Tegaljaya, dari 5.549 orang menjadi 5.703 orang. Akan tetapi dari tahun $2016-2017$ jumlah anggota koperasi kredit kubu gunung tegaljaya mengalami penurunan dari 5.703 orang menjadi 5.057 orang. Oleh sebab itu maka Koperasi Kubu Gunung Tegal Jaya perlu dicermati dikarenakan berkurangnya minat masyarakat dalam menggunakan jasa koperasi tersebut yang dapat dilihat melalui penurunan jumlah anggota koperasi tersebut. hasil penelitian dari Sumajow (2013) menyatakan bahwa secara persial variable suku bunga kredit berpengaruh terhadap permintaan kredit usaha kecil pada BRI unit Tareran. Artinya semakin tinggi suku bunga kredit menyebabkan minat masyarakat untuk memanfaatkan fasilitas kredit usaha kecil semakin berkurang. Menurut Sukirno (1994) Semakin rendah tingkat bunga yang harus dibayar para pengusaha maka semakin banyak pengusaha yang memakai layanan tersebut untuk berinvestasi. Tingkat suku bunga berkaitan dengan peranan waktu didalam kegiatan-kegiatan ekonomi. Tingkat suku bunga muncul dari kegemaran untuk mempunyai uang sekarang.

Prastyo (2009) bunga adalah harga dari (penggunaan) leonable funds, atau bisadiartikan sebagai dana yang tersedia untuk di pinjamkan atau dana investasi, karena menurut teori klasik, bunga adalah harga yang terjadi di pasar investasi. Investasi juga merupakan tujuan dari tingkat bunga. Suku bunga merupakan biaya modal bagi perusahaan (Sujoko, 2007).

Teori klasik menyatakan bahwa bunga adalah harga dari loanable funds (dana investasi) dengan demikian bunga adalah harga yang terjadi di pasar dan investasi. Menurut teori Keynes tingkat bunga merupakan suatu fenomena mon- 
eter. Artinya tingkat bunga ditentukan oleh penawaran dan permintaan akan uang (ditentukan di pasar uang).

Dalam industri berbankan yang sangat kompetitif, penentuan tingkat bunga kredit menjadi suatu alat persaingan yang sangat strategis. Bank-bank yang mampu mengendalikan pokok dalam penentuan tingkat bunga kredit (lending rate) akan mampu menetukan bunga kredit yang lebih rendah dibandingkan dengan bank-bank lainnya.

Menurut Carl dan Fair (2001:635) tingkat bunga adalah pembayaran bunga tahunan dari suatu pinjaman, dalam bentuk persentase dari pinjaman yang diperoleh dari jumlah bunga yang diterima tiap tahun dibagi dengan jumlah pinjaman. Pengertian tingkat bunga adalah harga dari pinjaman.Tingkat bunga dinyatakan sebagai persentase uang pokok per unit waktu. Bunga merupakan suatu ukuran harga sumber daya yang digunakan oleh debitur yang harus dibayarkan kepada kreditur.

Menurut Boediono (2005) Tingkat bunga adalah sebagai harga dari penggunaan uang untuk jangka waktu tertentu atau harga bunga yang harus dibayar apabila terjadi pertukaran antara satu rupiah sekarang dan satu rupiah nanti. Tingkat bunga merupakan biaya oppurtunitas dari memegang uang yang tidak menghasilkan bunga. Ketika tingkat bunga naik orangorang ingin memegang lebih sedikit uang. Orang-orang yang memegang kelebihan jumlah uang yang beredar berusaha mengubah sebagian diantaranya dari bentuk uang yang tidak menghasilkan bunga menjadi deposito di bank atau obligasi yang dapat menghasilkan bunga. Apabila tingkat bunga menjadi lebih rendah, lebih banyak usaha yang mempunyai tingkat pengembalian modal yang lebih tinggi daripada tingkat suku bunga. Semakin rendah tingkat bunga yang harus dibayar para pengusaha. Semakin rendah tingkat bunga semakin banyak investasi yang dilakukan para pengusaha. (Sukirno : 1998). Selain tingkat suku bunga, promosi juga diyakini mempengaruhi minat masyrakat dalam menggunakan jasa koperasi kredit kubu gunung tegal jaya di desa pancasari. Menurut Kotler (2000) mengatakan bahwa promosi merupakan salah satu faktor yang tidak dapat diabaikan untuk mema- suki pasar dan persaingan, karena promosi merupakan salah satu bagian dari proses komunikasi yang mempertemukan pembeli dan penjual dalam suatu hubungan kegiatan pertukaran yang lebih efisien dan meningkatkan semua pihak untuk mencapai persetujuan pertukaran yang memuaskan. Menurut Bell dalam Basu Swasta \& Irawan (2003:349) promosi adalah semua jenis kegiatan pemasaran yang ditujukan untuk mendorong permintaan. Sedangkan menurut Nikels dalam Basu Swasta dan Irawan (2003:349) promosi adalah arus informasi atau persuasi satu arah yang dibuat untuk mengarahkan seseorang atau organisasi kepada tindakan yang menciptakan pertukaran dalam pemasaran.

Kedua definisi tersebut pada pokoknya sama meskipun titik beratnya berbeda. Definisi pertama lebih menitik beratkan pada pendorongan permintaan. Sedangkan definisi kedua lebih menitik beratkan pada penciptaan pertukaran. Pertukaran akan terjadi karena adanya permintaan dan penawaran, dengan adanya permintaan akan mendorong terciptanya pertukaran. Jadi promosi merupakan salah satu aspek yang penting dalam manajemen pemasaran dan sering dikatakan sebagai proses berlanjut. Dengan promosi menyebabkan orang yang sebelumnya tidak tertarik untuk membeli suatu produk akan menjadi tertarik dan mencoba produk sehingga konsumen melakukan pembelian. Hasil penelitian yang dilakukan oleh Nur'aeni (2013) menyatakan bahwa promosi perbankan syariah berpengaruh terhadap minat masyarakat dalam memilih bank. tidak hanya tingkat suku bunga kredit dan promosi, kepuasan anggota koperasi juga diyakini mampu mempengaruhi minat masyarakat dalam menggunakan jasa koperasi kredit kubu gunung tegaljaya di desa pancasari karena menurut Kotler dan Keller (2000: 138) kepuasan anggota merupakan perasaan senang atau kecewa seseorang yang muncul setelah membandingkan antara kinerja (hasil) produk yang dipikirkan terhadap kinerja yang diharapkan.

Puas tidaknya anggota diketahui setelah melakukan transaksi, tergantung pada kinerja karyawan dalam pemenuhan harapan anggota. Jika kinerja berada dibawah harapan, anggota tidak puas. 
Juika kinerja memenuhi harapan, anggota puas. Jika kinerja melebihi harapan, anggota amat puas atau senang. Hasil penelitian yang dilakukan oleh olii (2016) menyatakan bahwa kepuasan pelanggan berpengaruh positif dan signifikan terhadap minat pembelian ulang. Selain tingkat suku bunga, promosi dan kepuasan anggota, sisa hasil usaha juga diyakini mampu menarik minat masyarakat dalam menggunakan jasa koperasi kredit kubu gunung tegal jaya di desa pancasari karena menurut Soemarsono (2007:56) Sisa hasil usaha merupakan keuntungan usaha yang dibagi sesuai dengan aktifitas ekonomi anggota koperasi. Menurut Sitio dan Tamba (2001:87), ditinjau dari aspek ekonomi manajerial, SHU koperasi adalah selisih dari seluruh pemasukan atau penerimaan total (total revenue [TR]) dengan biayabiaya atau biaya total (total cost [TC]) dalam satu tahun buku. Sisa hasil usaha dalam koperasi merupakan pendapatan yang diperoleh dalam satu tahun dikurangi penyusutan dan beban-beban dari tahun buku yang bersangkutan. Pada hakikatnya sisa hasil usah sama dengan laba untuk perusahaan yang lain (Soemarno, 2005:2008). Sehingga besaraan SHU yang diterima oleh setiap anggota akan berbeda, besar dan kecilnya nominal yang didapat dari SHU tergantung dari besarnya partisipasi modal dan transaksi anggota terhadap pembentukan pendapatan koperasi. Maksudnya adalah semakin besar transaksi anggota dengan koperasinya, maka semakin besar pula SHU yang akan diterima oleh anggota tersebut. semakin besar SHU koperasi maka semakin banyak anggota yang tertarik menggunakan jasa koperasi tersebut. Hasil penelitian yang dilakukan oleh Fitri (2012) menyatakan bahwa tidak terdapat pengaruh yang signifikan antara pendapatan koperasi dengan minat untuk menjadi anggota koperasi. kemudian faktor terakhir yang diyakini mempengaruhi minat masyarakat dalam menggunakan jasa koperasi kredit kubu gunung tegaljaya di desa pancasari adalah kinerja karyawan koperasi tersebut. Menurut Prawirosentono (1992:2) mengungkapkan bahwa kinerja karyawan merupakan hasil kerja yang dapat dicapai oleh seseorang atau sekelompok orang dalam suatu organisasi sesuai dengan wewenang dan tanggung jawabnya masing-masing. Prawirosentono (1992:2) mengungkapkan bahwa kinerja karyawan merupakan hasil kerja yang dapat dicapai oleh seseorang atau sekelompok orang dalam suatu organisasi sesuai dengan wewenang dan tanggung jawabnya masing-masing.

Kinerja apabila dikaitkan dengan performance sebagai kata benda (noun), maka pengertian performance atau kinerja adalah hasil kerja yang dapat dicapai oleh seseorang atau kelompok orang dalam suatu perusahaan sesuai dengan wewenang dan tanggung jawab masing-masing dalam upaya pencapaian tujuan perusahaan secara ilegal, tidak melanggar hukum dan tidak bertentangan dengan moral dan etika. Harsuko (2011).

Menurut Sinambela, dkk (2012) mengemukakan bahwa kinerja karyawan didefinisikan sebagai kemampuan pegawai dalam melakukan sesuatu keahlian tertentu. Kinerja karyawan sangatlah perlu, sebab dengan kinerja ini akan diketahui seberapa jauh kemampuan karyawan dalam melaksanakan tugas yang dibebankan kepadanya. Untuk itu diperlukan penentuan kriteria yang jelas dan terukur serta ditetapkan secara bersama-sama yang dijadikan sebagai acuan.

Kinerja merupakan istilah yang berasal dari kata Job Performance atau Actual Perfor-mance (prestasi kerja atau prestasi sesung-guhnya dicapai seseorang). Kinerja (prestasi kerja) adalah "hasil kerja secara kualitas dan kuantitas yang dicapai seorang pegawai dalam melaksanakan tugasnya sesuai dengan tanggung jawab yang diberikan kepadanya" (Mangkunegara, 2005:9).

Dari beberapa uraian para ahli diatas maka dapat disimpulkan bahwa kinerja adalah hasil kerja yang telah dicapai oleh karyawan yang berorientasi pada tujuan perusahaan. Setiap kinerja harus dinilai untuk mengetahui sejauh mana hasil kerja yang telah dicapai. Semakin baik kinerja karyawan maka perusahaan akan dipandang bagus dimata masyarakat dan membuat seseorang untuk tertarik untuk membeli ataupun menggunakan jasa perusahaan tersebut. Prawisentono (1999:221) berpendapat bah-wa, "manfaat penilaian kinerja karyawan yang dilakukan secara objektif, tepat dan didokumentasikan secara baik cenderung menurun 
potensi penyimpangan yang dila-kukan karyawan, sehingga kinerjanya diharapkan harus bertambah baik sesuai dengan kinerja yang dibutuhkan perusaha-an". Disamping itu penilaian kinerja karya-wan merupakan sarana untuk memperbaiki karyawan yang tidak melakukan tugasnya dengan baik dan membuat karyawan mengetahui posisi dan perannya dalam menciptakan tercapainya tujuan perusahaan. Hal tersebut akan menambah motivasi karyawan untuk berkinerja lebih baik lagi, karena masing-masing dapat bekerja lebih baik dan benar sesuai dengan tanggung jawabnya.

Hasil penelitian yang dilakukan oleh Kristanto (2014) menyatakan bahwa secara bersama-sama variabel efektifitas berpengaruh positif dan signifikan terhadap minat nasabah, variabel tanggung jawab berpengaruh positif dan signifikan terhadap minat nasabah, variabel disiplin berpengaruh positif dan signifikan terhadap minat nasabah, variabel Inisiatif tidak berpengaruh signifikan terhadap minat nasabah, variabel Efektifitas, Tanggung jawab, Disiplin, Inisiatif Berpengaruh secara bersama-sama dan signifikan terhadap minat nasabah. Jadi dari paparan para ahli dan penelitian sebelumnya maka faktor-faktor yang mampu mempengaruhi menurunnya minat masyarakat dalam menggunakan jasa koperasi kredit Kubu Gunung Tegal Jaya Di Desa Pacasari adalah tingkat suku buga, promosi, kepuasan anggota, sisa hasil usaha, dan kinerja karyawan. Berdasarkan pendahuluan di atas maka tujuan dari penelitian ini adalah untuk menganalisis faktor - faktor yang mempengaruhi minat masyarakat dalam menggunakan jasa koperasi kredit kubu gunung tegaljaya di desa pancasari.

\section{METODE}

Penelitian ini menggunakan rancangan penelitian kuantitatif kausal yang digunakan untuk memperoleh temuan yang teruji mengenai Analisis Faktor Faktor Yang Mempengaruhi Minat Masyarakat Dalam Menggunakan Jasa Koperasi Kredit Kubu Gunung Tegaljaya Di Desa Pancasari. Menurut Sugiyono (2007), desain kausalitas dapat dilakukan dengan langkah-langkah sebagai berikut: (a) merumuskan masalah, (b) landasan teori, (c) merumuskan hipotesis, (d) melakukan penelitian, (e) mengumpulkan data dan analisis data, dan (f) menyusun laporan dan menyimpulkan. Subjek penelitian ini adalah Kopdit Kubu Gunung Tegaljaya sedangkan objek penelitian adalah Tingkat Suku Bunga $\left(\mathrm{X}_{1}\right)$, Promosi $\left(X_{2}\right)$, Kepuasan Anggota $\left(X_{3}\right)$, SHU $\left(X_{4}\right)$, Kinerja Karyawan $\left(X_{5}\right)$ dan Minat Masyarakat $(Y)$. Jenis data yang digunakan dalam penelitian ini adalah data kuantitatif berupa data Jumlah Anggota-2017 tahun 2015. Sumber data dalam penelitian ini adalah data sekunder, yang diperoleh dari Tahunan Koperasi Kredit Kubu Gunung Tegaljaya tahun 2015-2017 berupa Rapat Anggota Tahunan (RAT).

Teknik pengumpulan data yang digunakan yaitu Pencatatan dokumen dengan mengambil data laporan tahunan Koperasi dan Teknik kuesioner. Skala yang digunakan dalam penyusunan kuesioner penelitian ini adalah ordinal. Menurut (Sugiyono, 2013:92) yaitu skala yang disusun secara runtut dari yang rendah sampai yang tinggi. Skala ordinal sekala yang diurutkan dari jenjang yang lebih tinggi sampai skala yang terendah atau sebaliknya.Adapun ciri-ciri dari skala ordinal antara lain : kategori data saling memisah, kategori data memiliki aturan yang logis, kategori data ditentukan skala berdasarkan jumlah karakteristik khusus yang dimilikinya. Setiap pernyataan disediakan 5 (lima) alternatif jawaban, yaitu sangat setuju (SS), setuju (S), ragu-ragu (RR), tidak setuju (TS), dan sangat tidak setuju (STS) dengan Skor 1-5.

Sesuai dengan rumusan masalah, tujuan penelitian, perumusan hipotesis, dan jenis data yang dikumpulkan, maka analisis data yang digunakan dalam penelitian ini yaitu Regresi Linier Berganda. Regresi berganda dilakukan untuk mengetahui sejauh mana variabel bebas mempengaruhi variabel terikat, baik secara parsial maupun simultan. Pada regresi berganda terdapat satu variabel terikat dan lebih dari satu variabel bebas. Dalam penelitian ini yang menjadi variabel bebas yaitu Tingkat Suku Bunga $\left(X_{1}\right)$, dan Promosi $\left(X_{2}\right)$, Kepuasan Anggota $\left(X_{3}\right)$, SHU $\left(X_{4}\right)$, dan Kinerja Karyawan $\left(X_{5}\right)$. Sedangkan yang menjadi variabel terikat adalah Minat Masyarakat $(Y)$. Model hubungan antar variabel tersebut dapat disusun dalam fungsi atau persamaan sebagai berikut: 
$Y=\alpha+\beta_{1} X_{1}+\beta_{2} X_{2}+\beta_{3} X_{3}+\beta_{4} X_{4}+\beta_{5} X_{5}$

(1)

Dimana :

Y : Minat Masyarakat

a : Konstanta atau titik perpotongan

dengan sumbu $Y$, bila $X=0$

$X_{1} \quad$ : Tingkat Suku Bunga

\section{HASIL DAN PEMBAHASAN}

Hasil

Pada penelitian ini diajukan empat hipotesis. Pengujian hipotesis digunakan analisis regresi linier berganda. Hasil re-
$\mathrm{X}_{2} \quad$ : Promosi

$\mathrm{X}_{3}$ : Kepuasan Anggota

$\mathrm{X}_{4}: \mathrm{SHU}$

$\mathrm{X}_{5} \quad$ : Kinerja Karyawan

$\beta_{1} \beta_{2} \beta_{3} \beta_{4} \beta_{5}$ : Koefisien regresi yang menyatakan perubahan nilai $Y$ akibat perubahan unit $\mathrm{X}$.

gresi berganda antara tingat suku bunga, promosi, kepuasan anggota, sisa hasil usaha (SHU) dan kinerja karyawan terhadap minat masyarakat secara simultan dapat dilihat pada Tabel 2.

Tabel 2. Output SPSS

\begin{tabular}{|c|c|c|c|c|c|c|}
\hline \multicolumn{7}{|c|}{ ANOVA $^{b}$} \\
\hline \multicolumn{2}{|c|}{ Model } & $\begin{array}{l}\text { Sum of } \\
\text { Squares }\end{array}$ & Df & $\begin{array}{l}\text { Mean } \\
\text { Square }\end{array}$ & $F$ & Sig. \\
\hline \multirow[t]{3}{*}{1} & $\begin{array}{l}\text { Regressio } \\
\mathrm{n}\end{array}$ & 2033.853 & 5 & 406.771 & $1.330 \mathrm{E} 3$ & $.000^{a}$ \\
\hline & Residual & 28.147 & 92 & .306 & & \\
\hline & Total & 2062.000 & 97 & & & \\
\hline
\end{tabular}

Sumber: Output SPSS

Berdasarkan hasil uji $\mathrm{F}$ pada Tabel 2 dapat diinterpretasikan sebagai berikut: Berdasarkan Tabel 2 ditunjukkan bahwa nilai $F$ sebesar 1.330 dengan nilai signifikansi 0,000 . Nilai signifikansi 0,000 lebih kecil dari 0,01 , sehingga $\mathrm{HO}$ ditolak dan $\mathrm{Ha}$ diterima. Jadi, dapat disimpulkan bahwa secara tingat suku bunga, promosi, kepuasan anggota, sisa hasil usaha (SHU) dan kinerja karyawan secara simultan berpengaruh signifikan terhadap minat masyarakat. Hasil uji koefisien determinasi dapat dilihat pada tabel 2 yang menunjukkan bahwa nilai Adjusted $R$ Square sebesar 0.986. Pada uji ini digunakan nilai Adjusted R2 , dimana nilai Adjusted R2 dapat naik atau turun apabila satu variabel independen ditambahkan ke dalam model. Hal ini mengindikasikan bahwa tingkat suku bunga, promosi, kepuasan anggota, sisa hasil usaha dan Kinerja karyawan merupakan faktor yang sangat mempengaruhi minat masyarakat dengan keeratan pengaruh sebesar 0.986. dan sisanya $0.014 \%$ adalah faktor lain yang mempengaruhi minat masyarakat.

Hasil regresi berganda antara tingat suku bunga, promosi, kepuasan anggota, sisa hasil usaha (SHU) dan kinerja karyawan terhadap minat masyarakat secara parsial dapat dilihat pada Tabel 3. 
Coefficients $^{a}$

\begin{tabular}{|c|c|c|c|c|c|c|}
\hline \multirow{2}{*}{\multicolumn{2}{|c|}{ Model }} & \multicolumn{2}{|c|}{$\begin{array}{l}\text { Unstandardized } \\
\text { Coefficients }\end{array}$} & \multirow{2}{*}{$\begin{array}{c}\begin{array}{c}\text { Standardize } \\
d \\
\text { Coefficients }\end{array} \\
\text { Beta }\end{array}$} & \multirow[b]{2}{*}{$\mathrm{t}$} & \multirow[b]{2}{*}{ Sig. } \\
\hline & & B & Std. Error & & & \\
\hline \multirow[t]{5}{*}{1} & (Constant) & -3.046 & .620 & & -4.916 & .000 \\
\hline & $\begin{array}{l}\text { tingkat suku } \\
\text { bunga }\end{array}$ & -.086 & .032 & -.082 & -2.658 & .009 \\
\hline & sisa hasil usaha & .400 & .047 & .447 & 8.540 & .000 \\
\hline & $\begin{array}{l}\text { kepuasan } \\
\text { anggota }\end{array}$ & .134 & .042 & .214 & 3.205 & .002 \\
\hline & kinerja karyawan & .099 & .020 & .085 & 4.838 & .000 \\
\hline
\end{tabular}

a. Dependent Variable: minat masyarakat

Sumber: Hasil Output SPSS

Berdasarkan hasil uji t pada Tabel 3 dapat diinterpretasikan sebagai berikut: Variabel Tingkat Suku Bunga (X1) memiliki koefisien negatif sebesar -0,086 dengan nilai signifikansi 0.009 . Nilai signifikansi lebih kecil dari nilai probabilitas $\alpha=0,01$, maka dapat dinyatakan bahwa Tingkat Suku Bunga (X1) berpengaruh signifikan terhadap Minat Masyarakat( $Y)$. Sedangkan, nilai koefisien regresi yang negatif menunjukkan bahwa Tingkat Suku Bunga (X1) berpengaruh negatif terhadap Minat Masyarakat(Y). Jadi, dapat disimpulkan bahwa $\mathrm{H} 1$ diterima sehingga Tingkat Suku Bunga berpengaruh signifikan negatif terhadap Minat Masyarakat. Variabel Promosi (X2) memiliki koefisien positif 0,203 dengan nilai signifikansi 0,000 . Nilai signifikansi lebih kecil dari nilai probabilitas $\alpha$ $=0,01$, maka dapat dinyatakan bahwa Promosi (X2) berpengaruhsignifikan terhadap Minat Masyarakat (Y). Sedangkan, nilai koefisien regresi yang positif menunjukkan bahwa Promosi (X2) berpengaruh positif terhadap Minat Masyarakat $(Y)$. Jadi, dapat disimpulkan bahwa $\mathrm{H} 2$ diterima sehingga Promosi berpengaruh signifikan positif terhadap Minat Masyarakat. Variabel Kepuasan Anggota (X3) memiliki koefisien positif 0.134 dengan nilai signifikansi 0,002 . Nilai signifikansi lebih kecil dari nilai probabilitas $\alpha=0,01$, maka dapat dinyatakan bahwa Kepuasan Anggota (X3) berpengaruh signifikan terhadap Mi- nat Masyarakat $(\mathrm{Y})$. Sedangkan, nilai koefisien regresi yang positif menunjukkan bahwa Kepuasan Anggota (X3) berpengaruh positifterhadap Minat Masyarakat (Y). Jadi, dapat disimpulkan bahwa H3 diterima sehingga Kepuasan Anggota berpengaruh signifikan positif terhadap Minat Masyarakat. Variabel Sisa Hasil Usaha (X4) memiliki memiliki koefisien positif 0.40 dengan nilai signifikansi 0,000 . Nilai signifikansi lebih kecil dari nilai probabilitas $\alpha=0,01$, maka dapat dinyatakan bahwa $\mathrm{SHU}(\mathrm{X} 4)$ berpengaruh signifikan terhadap Minat Masyarakat (Y). Sedangkan, nilai koefisien regresi yang positif menunjukkan bahwa Sisa Hasil Usaha(X4) berpengaruh positif terhadap Minat Masyarakat (Y). Jadi, dapat disimpulkan bahwa $\mathrm{H} 4$ diterima sehingga Sisa Hasil Usaha berpengaruh signifikan positif terhadap Minat Masyarakat. Variabel Kepuasan Anggota (X5) memiliki koefisien positif 0,99 dengan nilai signifikansi 0,000. Nilai signifikansi lebih kecil dari nilai probabilitas $\alpha=0,01$, maka dapat dinyatakan bahwa Kepuasan Anggota (X5) berpengaruh signifikan terhadap Minat Masyarakat (Y). Sedangkan, nilai koefisien regresi yang positif menunjukkan bahwa Kepuasan Anggota (X5) berpengaruh positifterhadap Minat Masyarakat (Y). Jadi, dapat disimpulkan bahwa H5 diterima sehingga Kepuasan Anggota 
berpengaruh signifikan positif terhadap Minat Masyarakat

\section{Pembahasan}

Hasil pengujian hipotesis mengenai pengaruh tingkat suku bunga, promosi, kepuasan anggota, sisa hasil usaha dan kinerja karyawan secara simultan terhadap minat masyarakat dan sisanya dipengaruhi oleh faktor lain. Faktor lain yang dimaksud yakni Super dan Crites (Lidyawatie, 1998) menjelaskan bahwa ada beberapa faktor yang mempengaruhi minat, yaitu : Perbedaan pekerjaan, artinya dengan adanya perbedaan pekerjaan seseorang dapat diperkirakan minat terhadap tingkat pekerjaan yang ingin dicapainya, aktivitas yang dilakukan, penggunaan waktu senggangnya, dan lain-lain. Perbedaan sosial ekonomi, artinya seseorang yang mempunyai sosial ekonomi tinggi akan lebih mudah mencapai apa yang diinginkannya daripada yang mempunyai sosial ekonomi rendah. Perbedaan hobi atau kegemaran, artinya bagaimana seseorang menggunakan waktu senggangnya. Perbedaan jenis kelamin, artinya minat wanita akan berbeda dengan minat pria, misalnya dalam pola belanja. Perbedaan usia, artinya usia anakanak, remaja, dewasa dan orangtua akan berbeda minatnya terhadap suatu barang, aktivitas benda dan seseorang.

Hasil penelitian menunjukkan bahwa persamaan regresi punya arah koefisien negatif. Pengaruh negatif menunjukkan bahwa hubungan tingkat suku bungaterhadap minat masyarakat adalah berbanding terbalik. Jika tingkat suku bunga tinggi, maka minat masyarakat akan semakin rendah. Hasil penelitian ini sesuai teori Sukirno (1998) yang menyatakan bahwa Semakin rendah tingkat bunga yang harus dibayar para pengusaha maka semakin banyak pengusaha yang memakai layanan tersebut untuk berinvestasi. Dan hasil penelitian ini didukung oleh penelitian Sumajow (2013) menyatakan bahwa secara persial variable suku bunga kredit berpengaruh terhadap permintaan kredit usaha kecil pada BRI unit Tareran. Artinya semakin tinggi suku bunga kredit menyebabkan minat masyarakat untuk memanfaatkan fasilitas kredit usaha kecil semakin berkurang.

Hasil penelitian menunjukkan bahwa persamaan regresi punya arah koefisien positif. Pengaruh positif menunjukkan bahwa hubungan antara promosi terhadap minat masyarakat adalah searah. Jika tingkat promosi baik, maka minat masyarakat akan semakin tinggi. Hasil penelitian ini sesuai dengan teori Kotler (2000) mengatakan bahwa promosi merupakan salah satu faktor yang tidak dapat diabaikan untuk memasuki pasar dan persaingan, karena promosi merupakan salah satu bagian dari proses komunikasi yang mempertemukan pembeli dan penjual dalam suatu hubungan kegiatan pertukaran yang lebih efisien dan meningkatkan semua pihak untuk mencapai persetujuan pertukaran yang memuaskan. Dan hasil penelitian ini didukung oleh Nur'aeni(2013) menyatakan bahwa promosi perbankan syariah berpengaruh terhadap minat masyarakat dalam memilih bank.

Hasil penelitian menunjukkan bahwa persamaan regresi punya arah koefisien positif. Pengaruh positif menunjukkan bahwa hubungan antara kepuasan angota terhadap minat masyarakat adalah searah. Jika tingkat banyak anggota yang merasa puas menggunakan layanan jasa koperasi, maka minat masyarakat akan semakin tinggi. Hasil penelitian ini sesuai dengan teori Kotler dan Keller (2009: 138) kepuasan anggota merupakan perasaan senang atau kecewa seseorang yang muncul setelah membandingkan antara kinerja (hasil) produk yang dipikirkan terhadap kinerja yang diharapkan. Puas tidaknya anggota diketahui setelah melakukan transaksi, tergantung pada kinerja karyawan dalam pemenuhan harapan anggota. Jika kinerja berada dibawah harapan, anggota tidak puas. Juika kinerja memenuhi harapan, anggota puas. Jika kinerja melebihi harapan, anggota amat puas atau senang. Dan didukung oleh penelitian olii (2016) menyatakan bahwa kepuasan pelanggan berpengaruh positif dan signifikan terhadap minat pembelian ulang.

Hasil penelitian menunjukkan bahwa persamaan regresi punya arah koefisien positif. Pengaruh positif menunjukkan bahwa hubungan antara Sisa Hasil Usaha terhadap minat masyarakat adalah searah. Semakin Tinggi Sisa Hasil Usaha, maka minat masyarakat akan semakin tinggi. Hasil penelitian ini sesuai dengan teori Soemarsono (2007:56) ysng meny- 
atakan bahwa Sisa hasil usaha merupakan keuntungan usaha yang dibagi sesuai dengan aktifitas ekonomi anggota koperasi. Sehingga besaraan SHU yang diterima oleh setiap anggota akan berbeda, besar dan kecilnya nominal yang didapat dari SHU tergantung dari besarnya partisipasi modal dan transaksi anggota terhadap pembentukan pendapatan koperasi. Maksudnya adalah semakin besar transaksi anggota dengan koperasinya, maka semakin besar pula SHU yang akan diterima oleh anggota tersebut. semakin besar SHU koperasi maka semakin banyak anggota yang tertarik menggunakan jasa koperasi tersebut. Dan juga didukung oleh penelitian yang dilakukan oleh Fitri (2012) menyatakan bahwa tidak terdapat pengaruh yang signifikan antara pendapatan koperasi dengan minat untuk menjadi anggota koperasi. kemudian faktor terakhir yang diyakini mempengaruhi minat masyarakat dalam menggunakan jasa koperasi kredit kubu gunung tegaljaya di desa pancasari adalah kinerja karyawan koperasi tersebut.

Hasil penelitian menunjukkan bahwa persamaan regresi punya arah koefisien positif. Pengaruh positif menunjukkan bahwa hubungan antara Kinerja Karyawan terhadap minat masyarakat adalah searah. Semakin bagus kinerja karyawan, maka minat masyarakat akan semakin tinggi. Hasil penetian ini sesuai dengan teori Prawirosentono (1992:2) mengungkapkan bahwa kinerja karyawan merupakan hasil kerja yang dapat dicapai oleh seseorang atau sekelompok orang dalam suatu organisasi sesuai dengan wewenang dan tanggung jawabnya masing-masing. Semakin baik kinerja karyawan maka perusahaan akan dipandang bagus dimata masyarakat dan membuat seseorang untuk tertarik untuk membeli ataupun menggunakan jasa perusahaan tersebut. Dan didukung oleh penelitian yang dilakukan oleh Kristianto (2014) yang menyatakan bahwa kinerja karyawan berpengaruh terhadap minat nasabah.

\section{SIMPULAN DAN SARAN Simpulan}

Berdasarkan hasil penelitian, maka dapat ditarik kesimpulan sebagai berikut: tingkat suku bunga pinjaman memiliki hubungan yang signifikan negatif terhadap minat masyarakat. Dimana semakin tinggi tingkat suku bunga pinjaman maka minat masyarakat untuk menggunakan jasa kredit koperasi akan berkurang, promosi memiliki hubungan yang signifikan positif terhadap minat masyarakat. Dimana semakin baik promosi yang dilakukan, maka akan semakin tinggi pula minat masyarakat untuk menggunakan jasa koperasi, kepuasan anggota memiliki hubungan yang signifikan positif terhadap minat masyarakat. Dimana semakin puas anggota dalam menggunakan jasa koperasi, maka koperasi tersebut dapat meningkatkan minat masyarakat dalam menggunakan jasannya, sisa Hasil Usaha (SHU) memiliki hubungan yang signifikan positif terhadap minat masyarakat. Dimana semakin tinggi SHU yang diterima anggota akan meningkatkan minat masyarakat dalam bergabung menjadi anggota koperasi dan memanfaatkan jasa koperasi karena ada imbal hasil yang akan diterima anggota setap tahunnya, kinerja karyawan memiliki hubungan yang signifikan positif terhadap minat masyarakat. Dimana semakin bagus kinerja karyawan maka akan dipandang bagus dimata masyarakat yang akan meningkatkan minat masyarakat dalam menggunakan layanan jasa koperasi.

\section{Saran}

Saran yang dapat diberikan adalah sebagai berikut: peneliti selanjutnya diharapkan agar mengembangkan variabel lain seperti perbedaan pekerjaan, perbedaan sosisal ekonomi, hobi, dan usia, memberikan informasi dalam mengembangkan koperasi khususnya dalam hal tingkat suku bunga, promosi, kepuasan anggota, sisa hasil usaha, dan kinerja karyawan guna untuk meningkatkan kinerja koperasi agar masyarakat semakin banyak ingin menggunakan jasa koperasi, peneliti selanjutnya diharapkanagar dapat mengembangkan objek penelitian dengan memperluas lokasi penelitian yang berbeda dan tidak hanya satu koperasi saja.

\section{DAFTAR PUSTAKA}

Anwar Prabu Mangkunegara. 2005. Sumber Daya Manusia perusahaan. Remaja Rosdakarya: Bandung Rudianto. 2006. Akuntansi Manajemen. Jakarta: PT Gramedia. 
Afgandi, lis Nur'aeni. 2012. Ternyata Wanita Lebih Mudah Masuk Surga. Bandung: Ruang Kata Imprint Kawan Pustaka.

Arifi. S \& Tamba. H. 2001. Koperasi : Teori dan Praktik. Jakarta: Erlangga

Kristanto. A. B. 2014. Musim sang juara. Penerbit Tatali News Cooperation: Bandung

Basu Swastha, dan Irawan. 2003. Manajemen Pemasaran Modern.Yogyakarta: Liberty Yogyakarta.

Boediono, Gideon SB. 2005. Kualitas Laba: Studi Pengaruh Mekanisme Corporate Governace dan Dampak Manajemen Laba dengan Menggunakan Analisis Jalur. Simposium Nasional Akuntansi VIII, Al, 2005.

Burhanuddin,S. 2010. Aspek Hukum Lembaga Keuangan Syariah. Yogyakarta: Graha IImu

Fitri, Yaumil. 2012. Pengaruh Pendapatan Koperasi Terhadap Minat Untuk Menjadi Anggota Pada Koperasi Unit Desa Mulya Mandiri Muara Nikum. Skripsi. Universitas Pasir Pengaraian Rokan Hulu

Karl \& Fair. 2001. Pembayaran Bunga Tahunan Dari Suatu Pinjaman, Dalam Bentuk Persentase Dari Pinjaman Yang Diperoleh. YKPN Yogjakarta

Kotler, Philip. 2000. Prinsip - Prinsip Pemasaran Manajemen, Jakarta : Prenhalindo.

Olii, Kevin Reno Reynard. 2016. Peran Kepuasan Pelanggan Dalam Memediasi Pengaruh Experiential Marketing Terhadap Pembelian Ulang Tiket Pesawat Pada Pt Jasa Nusa Wisata Denpasar. Skripsi. Universitas Udayana

Prasetyo, P. Eko. 2009. Fundamental Makro Ekonomi. Yogyakarta: Beta Offset

Prawirosentono.S. 1999. Manajemen Sumber Daya Manausia, Kebijakan Kinerja Karyawan. BPFE, Yogyakarta.
Razak, Razak. 2012. Ekonomi Koperasi dan UKM. Malang: Universitas Negeri Malang

Riniwati, Harsuko. 2011. "Mendongkrak Motivasi dan Kinerja: Pendekatan Pemberdayaan SDM". Malang: UB Press

Sinambela, Lijan. 2012. Kinerja Pegawai: Teori, Pengukuran dan Implikasi. Yogyakarta: Graha IImu

Sugiyono. 2007. Metode Penelitian Kuantitatif Kualitatif dan R\&D. Bandung: Alfabeta

Sugiyono. 2013. Metode Penelitian Pendidikan Pendekatan Kuantitatif, Kualitatif, dan R\&D. Bandung: Alfabeta

Sujoko \& Ugy Soebiantoro. 2007. Pengaruh Struktur Kepemilikan Saham, Leverage, Faktor Interen dan Faktor Eksteren terhadap Nilai Perusahan. Jurnal Manajemen dan Kewirausahaan. Vol 9 (1)

Sukirno, Sadono. 1994. Pengantar Teori Ekonomi. Jakarta: PT. Raja Grafindo Persada.

Undang - Undang Republik Indonesia No. 17 Tahun 2012 Tentang Perkoperasian, Kementrian Koperasi dan Usaha Kecil \& Menengah, Republik Indonesia 2012 